findings by Demin (1970) in the region of Kangerdluarssuk and thus a general evolution scheme seems valid for the whole length of the lujavrite breccia.

One of us (J. C.) constructed a net of geodetic reference points covering the southern part of the intrusion. With a few exceptions the points are determined with an accuracy better than $5 \mathrm{~m}$. The point density is highest north-west of Lakseelv with distances of a few hundred metres. In the rest of the intrusion base-lines defined by two points can generally be found within $1 \mathrm{~km}$.

K. M. and P. N. spent a week mapping in detail the boundary between sodalite-foyaite and naujaite. The results have not yet been fully analysed, but the first impression is that the boundary surface can be regarded as a series of planes with slightly varying dip and strike. Locally, at least, there is indication that the banding in the naujaite is discordant with the boundary. This might indicate that rearrangements took place in the magma chamber when crystallisation changed from a foyaitic to a naujaitic stage. This is further substantiated by the knife-sharp western contact, which is replaced by the gradual transition farther to the east.

\title{
References
}

Andersen, S. 1974: Detailed mapping in the southern part of the Ilimaussaq alkaline intrusion, South Greenland. Rapp. Grønlands geol. Unders. 65, 69-71.

Andersen, S., Bailey, J., Karup-Møller, S., Løkkegaard, L., Rose-Hansen, J., Steenfelt, A. \& Sørensen, H. 1973: Research projects on the Ilimaussaq alkaline intrusion, South Greenland. Rapp. Grønlands geol. Unders. 55, 38-40.

Demin, A. 1970: Detailed mapping in the southern part of the Ilimaussaq intrusion (Kangerdluarssuk fjord). Rapp. Grønlands geol. Unders. 35, 29-30.

S. A., K. M., \& P. N.,

J. C., Institut for Petrologi, Højskolen Søtoftegård; University of Copenhagen, 4100 Ringsted.

Øster Voldgade 5-7,

1350 Kobenhavn $\mathrm{K}$.

\section{Environmental, geochemical and ecological studies in the region around the Ilimaussaq alkaline intrusion, South Greenland}

\section{Compiled by C. Overgaard Nielsen, John Rose-Hansen and Henning Sørensen}

This work was undertaken jointly by GGU and the Danish Natural Science Research Foundation (SNF) and was a continuation of the 'Narssaq project', initiated in 1974 (Bohse et al., 1975). In 1975, G. Asmund of GGU and the following members of the University 
of Copenhagen, took part in the investigations - N. Christensen, J. Feilberg, R. Gwozdz, M. M. Hansen, J. Jørgensen, C. L. Larsen, K. Lindegaard-Petersen, P. Mæhl, B. Nielsen, C. O. Nielsen; D. Olsen, H. Sørensen, P. Willumsen and the present compiler.

The main aim of the project is to compare the exogeneous, geochemical and ecological environments in various areas within the Ilimaussaq alkaline intrusion with selected reference areas in the Julianehåb granite terrain outside the intrusion. There were five main studies in 1975 and these are briefly outlined below.

\section{Water balance studies}

Water balance studies in the Narssaq Elv-Dyrnes region were initiated in 1965 as part of the Danish contribution to the Unesco International Hydrologicá Decade (IHD) (Hansen \&

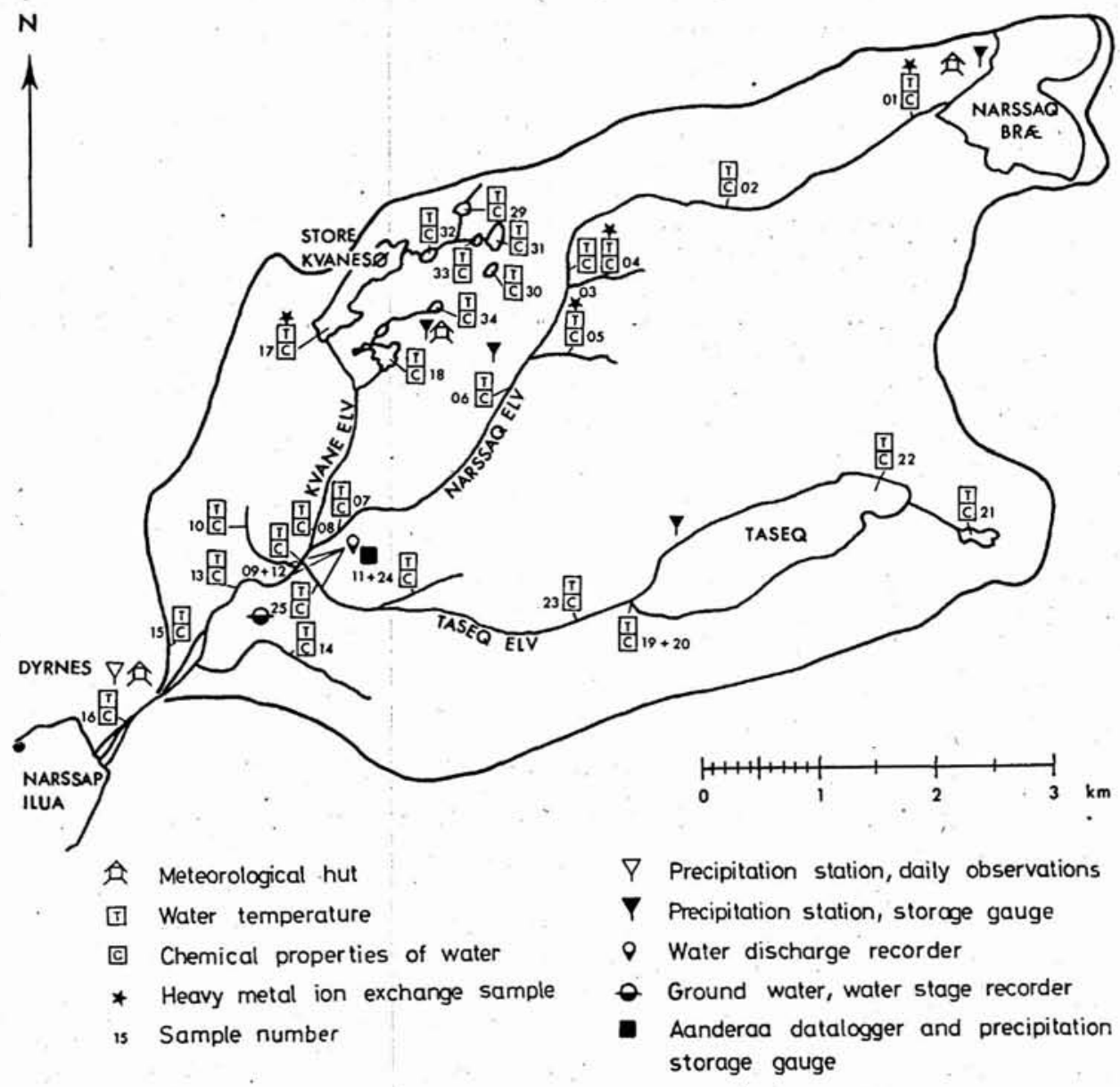

Fig. 30. Map of the Narssaq Elv - Dyrnes region, South Greenland showing the location of the main recording equipment. 
Pulawski, 1966; Larsen, 1972). In 1972 these studies were expanded with new water stage recorders and the discharge of the river Narssaq Elv was determined by current meter and salt dilution method. The maximum discharge registered during the field season in the Narssaq Elv was $10 \mathrm{~m}^{3} / \mathrm{sec}$.

An Aanderaa datalogger was set up in the Narssaq Elv valley to extend the observation

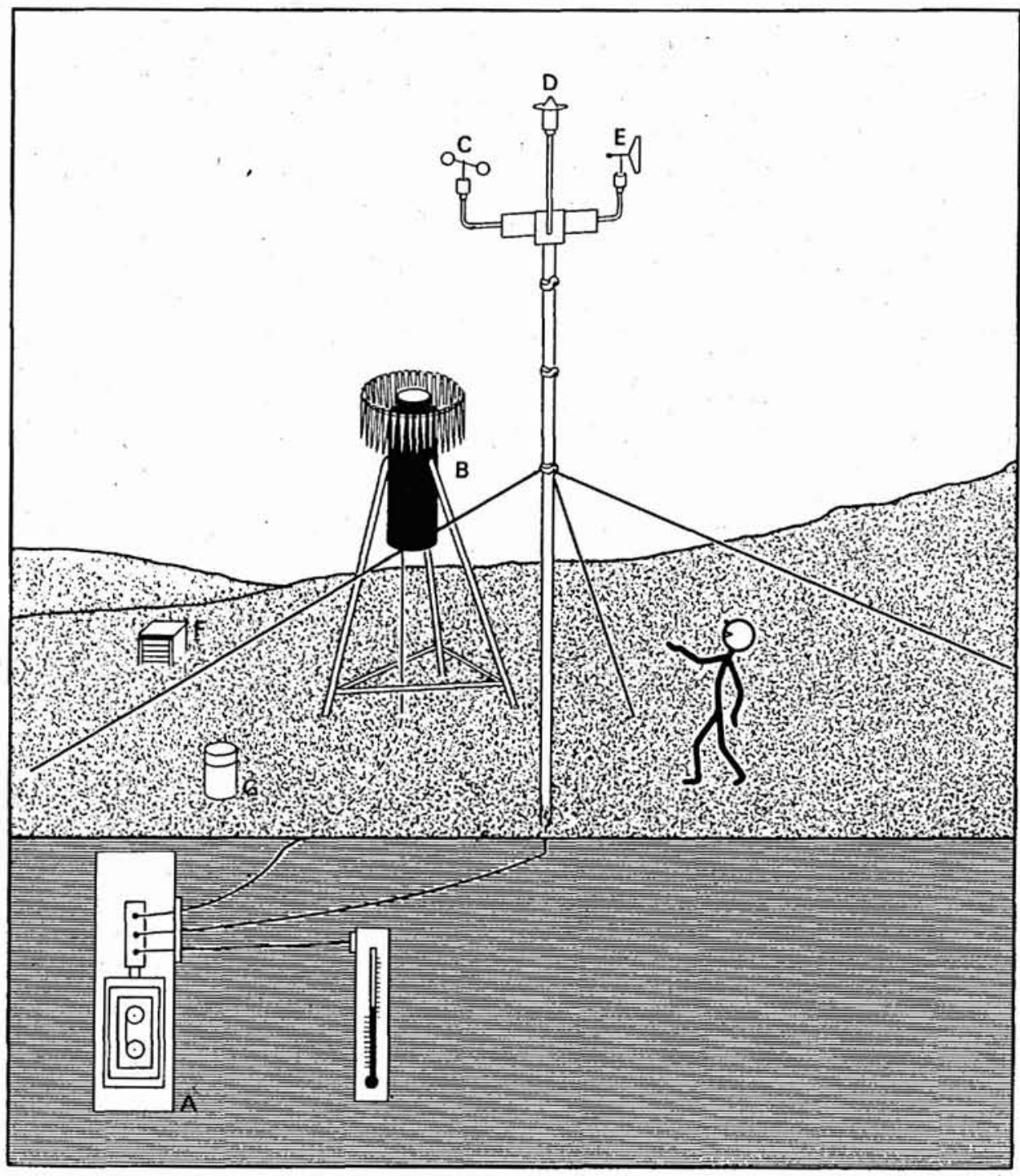

Fig. 31. Detail of the climatic recording equipment used in the Kangerdluarssuk region, South Greenland. A - Datalogger; B - Precipitation totaliser, height $3 \mathrm{~m}$; C-Wind speed sensor; D-Solar radiation sensor; E - Wind vane; F - Stephenson screen; G - Precipitation gauge. 
period through the winter. The datalogger was connected to thermistors to measure the air and river water temperatures and the temperature of different soil depths. The datalogger was also connected to pressure transducers to measure the water level in a precipitation totaliser and in the rivers Taseq Elv, Kvane Elv and Narssaq Elv.

A similar datalogger was placed in the Kangerdluarssuk area to the south of the Narssaq Elv - Dyrnes region. It was connected to sensors for wind direction, wind speed, solar radiation, air pressure and dew point (fig. 31).

The dataloggers are placed at a depth of $2.5 \mathrm{~m}$ in a polymer tube partly set in concrete and insolated with polystyrene foam in order to keep the equipment above the minimum working temperature of $-5^{\circ} \mathrm{C}$. Readings from the datalogger are taken every two hours throughout the year.

The ablation of a local glacier, Narssaq Bræ, was determined by measuring the levels of sticks placed in the glacier, by photos and by snow evaluation.

Selected lakes in the area were surveyed from a small rubber boat. The biggest lakes in the area are Taseq measuring $1.75 \mathrm{~km}^{2}$ with a maximum depth of $c .36 \mathrm{~m}$ and a volume of $18 \times 10^{6}$ $\mathrm{m}^{3}$ (Hansen \& Pulawski, 1966) and Fosters $\varnothing$, measuring $0.4 \mathrm{~km}^{2}$ with a maximum depth of more than $60 \mathrm{~m}$.

Ground water was studied at a few localities.

Temperature, $\mathrm{pH}$, conductivity and free oxygen were measured at many localities and many water samples were collected for chemical analysis. Selective ion exchange probes which concentrate some heavy elements by a factor of 100000 were placed in selected rivers and streams for 14 days.

The recorded surface temperature of the lakes varied from 5 to $20^{\circ} \mathrm{C}$. The $\mathrm{pH}$ of the surface water was in the range of 6.5 to 7.5. The lakes and rivers are generally saturated with free oxygen but only a few plants and animals were found.

Uranium rich water near the Narssaq Bræ. (Asmund, 1975) comes from areas where the water percolates red- coloured shear zones in volcanic rocks which contain uranium in iron oxides. This uranium thus appears to be more easily soluble at surface conditions than uranium bound in the steenstrupine and monazite of the lujavrites.

\section{Weathering and soil formation}

A study of weathering was undertaken on drill cores and hand samples. Many soil profiles were dug and sediments collected from rivers, lakes and fjords. The following soils were found: Syrosem soil, Ranker soil, brown soil (characterized by a humic upper horizon and a brown coloured second horizon) and podsolic soil (nomenclature after Kubiena, 1953).

Podsolic soil is the last stage in the soil development. Between 1.8.1974 to 1.7.1975 the downslope mass movement was found to be 10 to $20 \mathrm{~cm}$ depending on the angle of the slope.

\section{Hydrography and marine biology}

The hydrography of the tidal zone was investigated near the head of the Kangerdluarssuk fjord. Kangerdluarssuk fjord was surveyed and $\mathrm{pH}$, temperature and salinity were measured in selected profiles. 
Many samples of lamellibranchs, gastropods, fishes and seaweed were collected for chemical analysis. Many bottom sediments were collected in order to study the content of foraminifera and the chemistry of the sediments.

\section{Botany}

A systematic study of the plant cover in the area was undertaken. Many plants were collected for chemical analysis, especially for heavy elements. Preliminary results indicate a high content of rare earth elements in the plants of the Ilimaussaq intrusion.

\section{Chemical analysis}

More than 500 of the biological, rock, mineral and water samples collected in 1974 were analysed by instrumental neutron activation analyses for about 40 elements.

The biological material was freeze-dried before analysis, and supplementary analyses were made for DDT, DDE, DDD, PBC and methyl mercury. The content of pesticides is very low. The sea water was analysed for $\mathrm{Zn}, \mathrm{Cd}, \mathrm{Pb}$ and $\mathrm{Cu}$ by anodic stripping voltametry.

The selective ion exchange probes were analysed for $\mathrm{Cu}, \mathrm{Pb}, \mathrm{Ni}, \mathrm{Zn}, \mathrm{Cr}, \mathrm{Cd}$, and $\mathrm{U}$. A few biological samples were analysed for $\mathrm{U}$ and $\mathrm{Th}$ by the delayed neutron method. More than 1000 samples have been analysed for $\mathrm{Li}$ by a method using the Czerenkow effect.

\section{References}

Asmund, G. 1975: Uranium content in rivers of the Narssaq area, South Greenland. Rapp. Gronlands geol. Unders. 75, 84-86.

Bohse, H., Larsen, L. M., Rose-Hansen, J., Nielsen, C. O. \& Sørensen, H. 1975: Current research on the Ilimaussaq alkaline intrusion, South Greenland. Rapp. Grønlands geol. Unders. 75, 81-83.

Hansen, J. \& Pulawski, B. 1966: Water balance in Narssaq river valley. Rapp. Grønlands geol. Unders. $11,50-51$.

Kubiena, W. L. 1953: Bestimmingsbuch und systematik der Böden Europas. Stuttgart: Ferdinand Enke Verlag.

Larsen, L. B. 1972: Hydrological project at Narssaq Bræ, South Greenland, as part of the international Hydrological Decade Programme. Rapp. Grønlands geol. Unders. 45, 27-29.

C. O.N.

Institut for almen Zoologi,

Universitetsparken 15 ;

2100 Copenhagen $\varnothing$
J. R.-H., H. S. Institut for Petrologi, University of Copenhagen, Øster Voldgade 5-7, 1350 Copenhagen $K$. 